\title{
Discussion on low-carbon economy and low-carbon building technology
}

\author{
Xiao-Gen Shuai ${ }^{1,2}$, Hui-Qiang Li $^{2}$ \\ ${ }^{1}$ CNNC Hunan Taohuajiang Nuclear Power CO., LTD, Yiyan 413000, P. R. China; ${ }^{2}$ School of Civil Engineering and Mechanics, \\ HUST, Wuhan 430074, P. R. China. \\ Email: shuaixiaogen@,smail.hust.edu.cn
}

Received 11 May 2009; revised 20 May 2009; accepted 26 May 2009.

\begin{abstract}
The paper introduced low-carbon economy and low-carbon technology, and proposed the detailed technical measures of low-carbon building technology. Moreover, it has quantitatively calculated the "implicit" $\mathrm{CO}_{2}$ emission of $\mathrm{C} 40$ and $\mathrm{C} 50$ concrete columns, aluminium curtain wall, wall paintings and common floor decoration materials. The calculation results show that it is preferable to use high strength concrete, reduce the usage of aluminium materials and use wooden floor according to location. The paper can be a reference for quantitative measurement to the low-carbon technology and energy efficiency.
\end{abstract}

Keywords: Low-Carbon Economy; Low-Carbon Technology; Building Technology; Quantitative Calculation

\section{INTRODUCTION}

The British energy white paper "Our Energy FutureCreating a Low Carbon Economy" firstly introduced the concept of "Low-carbon Economy" [1]. This concept means that the developed industrial country should use the production technology that reduces the emission of $\mathrm{CO}_{2}$, so as to protecting the environment while maintaining the economic growth. The $\mathrm{CO}_{2}$ and ozone etc. in the aerosphere can absorb the radiant heat from sun and preventing its escape from the earth, therefore empowering the aerosphere of the natural greenhouse effect. When the density of greenhouse gases such as $\mathrm{CO}_{2}$ raises, the absorbed radiant heat will increase and the heat given out by the earth will be reduced, thus resulting in global warming. Global warming will melt the glacier, raise the sea level, reduce the continental area, silt up harbors and destroy the marsh land and river plain, as a result bringing great negative effects to the eco- nomic of coastland area. Moreover, global warming will shift the climate zone to high latitude, change the ecosystem in certain area and increase infectious diseases and the consumption of ozonosphere [2].

White paper: China's policies and actions on climate change [3] issued by the Chinese government has indicated that, the average temperature of the earth surface in China has increased by $1.1^{\circ} \mathrm{C}$ during the last 100 years. For the last 30 years, the sea level has increased by $90 \mathrm{~mm}$ on average. For example, the 《Assessment Report on Climate Change of Guangdong》 [4] issued by the weather bureau of Guangdong Province in 2007 forecast that, in the background of global warming, the emission of greenhouse gases such as $\mathrm{CO}_{2}$ will be doubled in Guangdong Province, and the sea level will increase by $30 \mathrm{~cm}$ (compared with the highest level in record), which is quite serious.

China is one of the first signing countries of $《$ Kyoto Protocol》, but it has not assumed its responsibility in reducing the emission of gas since it is still a developing country. However, China has a growing power in the economic world, and as a responsible major country China has to face the question of reducing the emission of greenhouse gases and develop a low-carbon economy during its economic growth.

The low-carbon technology has relationships with electricity sector, transportation sector, construction sector, chemistry industry and many other new technologies. Price L. et al [5] and Kim Y [6] have studied the energy demand and $\mathrm{CO}_{2}$ emission of Chinese steel industry; and Yang J X [7] have conducted bill analysis over the life cycle of steel industry. Low-carbon building technology is a multi-disciplined subject. Based on the building design and selection of building materials, the paper adopts the life cycle assessment to quantitatively analyze the emission of $\mathrm{CO}_{2}$ and studies the low-carbon building technology, in expecting to provide a brand-new angle for energy saving and green building. 


\section{ENERGY SAVING AND EMISSIONS REDUCTION}

Energy saving in buildings relates to building planning, building design, retaining structure, heating system, airconditioning system design, lighting system and many other sectors [8]. At present, many energy saving methods have been carried out in construction projects, including heat preventing technology in surrounding structure, usage of solar power and wind power, energy saving in temperature control, and enhancing energy saving management; they all have a positive impact on energy saving and emission reduction $[9,10,11]$. However, the author of this article feels that all these works are "explicit" energy saving and carbon reducing works; for example, the heat preventing technology in surrounding structure puts more attention to the energy saving during the running of buildings. But they have not considered the massive consumption of building materials and energy during the construction of the project, the massive emission of greenhouse gases such as $\mathrm{CO}_{2}$ during the collection, artificial work and transportation process. Low-carbon emission measures should also be taken to them, and these measures can be called "implicit" carbon reducing measures. In this sense, lowcarbon building technology should take into consideration of both the "explicit" and "implicit" low-carbon technology.

\section{LOW-CARBON BUILDING TECHNOLOGY}

From the point of low-carbon building technology, it should be taken into consideration of choosing materials and components with lower carbon emission during the designing and construction process.

\subsection{Low-Carbon Technology in Structure Designing}

The paper takes the ground floor structure of a five-story frame structure industrial workshop of a chemical factory as the example. It compares the $\mathrm{C} 40$ concrete with the C50 concrete through the PKPM structure designing software, both of which are under the same structure load and seismic designing requirement. And the change in sectional area are shown in Figure 1, when C40 has

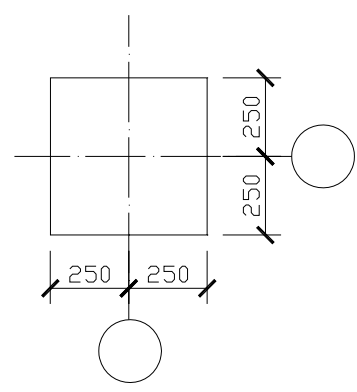

(a) $\mathrm{C} 40$

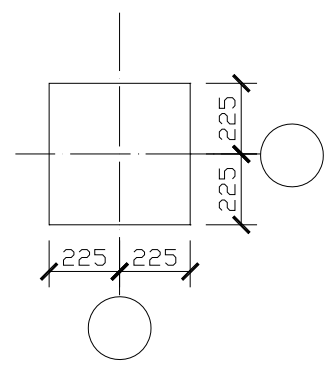

(b) $\mathrm{C} 50$
Figure 1. Section of concrete columns. been upgraded to C50 with the same amount of reinforcements; and the length of each side in section has been reduced by $50 \mathrm{~mm}$ in most of columns.

The mixed ratios of concrete used by this article have been listed in Table 1. The $\mathrm{CO}_{2}$ emission of concrete production is $1041.6 \mathrm{~kg} \mathrm{CO}_{2} / \mathrm{t}$ [12]. According to the investigation of building materials procurement in Wuhan, the transportation distance of concrete used by the concrete batching plant is $50 \mathrm{~km} \sim 200 \mathrm{~km}$; which is taken as $100 \mathrm{~km}$ for the convenience of following calculation. The transportation distance for sand and gravels is $50 \mathrm{~km}$, and the distance for concrete from the concrete batching plant to the construction site is $50 \mathrm{~km}$; moreover, according to references [13], the energy consumption of sand and gravel is $13.89 \mathrm{kw} \cdot \mathrm{h} / \mathrm{t}$, and that of concrete is 2 $\mathrm{kw} \cdot \mathrm{h} / \mathrm{m}^{3}$. All the materials will be transported by $5 \mathrm{t}$ trucks, and the amount of $\mathrm{CO}_{2}$ emission during the transportation and electricity production is referred to reference [14]. The $\mathrm{CO}_{2}$ emission calculation of $1 \mathrm{~m}^{3}$ concrete in using the bill analysis (a type of life cycle assessment method) under the two strength levels have been listed as follows.

Through the calculation, when the columns in ground floor using the $\mathrm{C} 40$ concrete, the quantity consumed is $30.996 \mathrm{~m}^{3}$, and the $\mathrm{CO}_{2}$ emission is $15994 \mathrm{~kg}$; when using the C50 concrete, the quantity consumed is $25.389 \mathrm{~m}^{3}$, and the $\mathrm{CO}_{2}$ emission is $15193 \mathrm{~kg}$. The consumption of concrete has been reduced by $5.607 \mathrm{~m}^{3}$, or $18.1 \%$; and $\mathrm{CO}_{2}$ consumption has been reduced by $801 \mathrm{~kg}$, or $5.0 \%$. In increasing the strength of concrete, the consumption of concrete and $\mathrm{CO}_{2}$ emission can be largely reduced. Therefore, high strength concrete should be preferable, with the satisfaction to structure safety and designing requirement.

Table 1. Mixed ratio of concrete.

\begin{tabular}{cccccc}
\hline \multirow{2}{*}{$\begin{array}{c}\text { Concrete } \\
\text { Strength Level }\end{array}$} & \multirow{2}{*}{$\begin{array}{c}\text { Cement } \\
\text { grade }\end{array}$} & \multicolumn{4}{c}{ Mixed ratio/(kg/m $\left./ \mathrm{m}^{3}\right)$} \\
\cline { 3 - 6 } & & cement & sand & crushed rock & water \\
\hline C40 & 525 & 460 & 720 & 1080 & 185 \\
C50 & 525 & 540 & 655 & 1070 & 185 \\
\hline
\end{tabular}

Table 2. $\mathrm{CO}_{2}$ emission of $\mathrm{C} 40$ and $\mathrm{C} 50$ concrete columns $\left(\mathrm{kg} / \mathrm{m}^{3}\right)$.

\begin{tabular}{lcc}
\hline \multicolumn{1}{c}{ Concrete Strength Level } & C40 & C50 \\
\hline Cement production & 479.1 & 562.5 \\
Cement transportation & 1.1 & 1.3 \\
Aggregate acquisition & 28.5 & 27.3 \\
Aggregate transportation & 2.1 & 2.1 \\
Concrete mixing & 2.3 & 2.3 \\
Concrete transportation & 2.9 & 2.9 \\
Total & 516.0 & 598.4 \\
\hline
\end{tabular}




\subsection{Low-carbon Technology in Building Materials}

The building components can be made from various building materials, while the "implicit" $\mathrm{CO}_{2}$ emission differs during the production of different building materials. The paper adopts the BEES assessment software developed by National Institute of Standards and Technology to calculate the "implicit" $\mathrm{CO}_{2}$ impact of different building materials. BEES (Building for Environmental and Economic Sustainability, BEES) is a comprehensive evaluation software over the construction environment and sustainability, and has been supported by the Association of American Environment Protection and U. S. Government [15]. It uses the Life Cycle Assessment (LCA) to quantitatively assess the environmental performance of building materials.

\subsubsection{Comparison Between Aluminium Curtain wall and wall Paintings}

There are enormous consumption of fossil fuel and $\mathrm{CO}_{2}$ emission in the production process of aluminium materials, and the energy consumption is $435 \mathrm{GJ} / \mathrm{t}$ while carbon emission is $8700 \mathrm{~kg} / \mathrm{t}$; but the figures in the production of steel materials are only $35 \mathrm{GJ} / \mathrm{t}$ and $700 \mathrm{~kg} / \mathrm{t}$, both of which are $1 / 12$ of that of aluminium materials [16]. Therefore, the usage of aluminium materials should be reduced, and other green materials should be adopted. This article has conducted a calculation over the aluminium curtain wall of a university refectory project, and has analyzed the difference of $\mathrm{CO}_{2}$ emission by switching to common wall paintings.

The "implicit" $\mathrm{CO}_{2}$ emission of $1 \mathrm{~m}^{2}$ aluminium curtain wall and common wall paintings have been calculated out by BEES software. For the convenience of calculation, it has been assumed that the transportation distance for both of them are $200 \mathrm{~km}$ with a life span of 50 years, then the quantity of $\mathrm{CO}_{2}$ emission are shown as follows.

As a result, the $\mathrm{CO}_{2}$ emission of aluminium curtain wall is far larger than that of common wall paintings. The quantity of aluminium curtain wall in this refectory project is $2519 \mathrm{~m}^{2}$, but if using the common wall paintings it will reduce $34476 \mathrm{~kg} \mathrm{CO}_{2}$ with an $85 \%$ reduction rate.

Table 3. Comparison between aluminium curtain wall and wall paintings $\left(\mathrm{gCO}_{2} / \mathrm{m}^{2}\right)$.

\begin{tabular}{ccccc}
\hline $\begin{array}{c}\text { life cycle } \\
\text { stage }\end{array}$ & $\begin{array}{c}\text { Raw } \\
\text { materials }\end{array}$ & Manufacturing & Transportation & Total \\
\hline $\begin{array}{c}\text { aluminium } \\
\text { curtain wall }\end{array}$ & 14131 & 1878 & 40 & 16050 \\
$\begin{array}{c}\text { wall paintings } \\
1755\end{array}$ & 566 & 42 & 2364 \\
\hline
\end{tabular}

Table 4. Comparison of floor decoration materials $\left(\mathrm{gCO}_{2} / \mathrm{m}^{2}\right)$.

\begin{tabular}{ccccc}
\hline $\begin{array}{c}\text { life cycle } \\
\text { stage }\end{array}$ & $\begin{array}{c}\text { Raw } \\
\text { materials }\end{array}$ & Manufacturing Transportation & Total \\
\hline $\begin{array}{c}\text { Composite } \\
\text { marble tile } \\
\text { Terrazzo } \\
\text { flooring }\end{array}$ & 25953 & 334 & 1679 & 27966 \\
$\begin{array}{c}\text { Wool } \\
\text { carpet tile } \\
\text { Natural } \\
\text { cork tile }\end{array}$ & 415673 & 2314 & 237 & 418213 \\
\hline
\end{tabular}

\subsubsection{Indoor Floor Decoration Materials}

Floor decoration material has been a major part of the total consumption and cost of a decoration project, thus the choices of materials have a close relationship with the "implicit" $\mathrm{CO}_{2}$ emission and indoor environment. This article has selected several common indoor floor decoration materials, and used the BEES software to calculate the "implicit" $\mathrm{CO}_{2}$ emission of $1 \mathrm{~m}^{2}$ indoor floor decoration materials for 50 years life span. For the convenience of calculation, it has been assumed that, the transportation distance of the material is $400 \mathrm{~km}$ with a life span of 50 years, then the quantity of their $\mathrm{CO}_{2}$ emission are as follows.

It is obvious to see the advantage of wooden floor in carbon reduction, while other materials have given out much $\mathrm{CO}_{2}$ in their whole life cycle; the animal-made materials have the most serious situation. Therefore, wooden materials should be selected if the local forests can sustainable provide the resources.

\section{CONCLUSIONS}

The paper has discussed the Low-carbon economy and Low-carbon building technology, and has proposed detailed technical measures of Low-carbon building technology. In satisfying the structure load and seismic designing requirements, the "implicit" $\mathrm{CO}_{2}$ emission can be reduced by approximately 5\% if replace $\mathrm{C} 40$ concrete by $\mathrm{C} 50$ concrete; the quantity of $\mathrm{CO}_{2}$ emission of the aluminium alloy curtain wall during the whole life cycle is $15 \%$ of that of the wall paintings with the same area; wooden floor has a much smaller quantity of "implicit" $\mathrm{CO}_{2}$ emission than other indoor floor decoration materials. The above measures and calculation results are of value as a reference for energy saving, emission reduction and low-carbon building technology.

\section{ACKNOWLEDGEMENTS}

This work is supported by the Special Research Foundation of Doctoral Subjects in University of China (No. 20050487017).

\section{REFERENCES}

[1] Department of Trade and Industry (2003) Our energy future-creating a low carbon economy. The Stationery Office, London. 
[2] Chris, H. (2002) Priorities for a low-carbon economy. New Economy, 9(1), 11-15.

[3] State council information office of the People's Republic of China (2008) White paper: China's policies and actions on climate change. http://www.chinanews.com.cn/ gn/news/2008/10-29/1429538.shtml.

[4] Composing team for Assessment Report on Climate Change of Guangdong (2007) Assessment report on climate change of Guangdong (Selection). Guangdong Meteorology (in Chinese), 29(3), 1-7.

[5] Price, L., Sinton, J., Worrell, E., et al. (2002) Energy use and carbon dioxide emissions from steel production in China. Energy, 27, 429-446.

[6] Kim, Y. and Worrell, E. (2002) International comparison of $\mathrm{CO}_{2}$ emission trends in the iron and steel industry. Energy Policy, 30, 827-838.

[7] Yang, J. X. and Liu, B. J. (2002) Life cycle inventory of steel products in China. Acta Scientiae Circumstantiae (in Chinese), 22(4), 519-522.

[8] Long, W. D., Bai, W. and Fan, R. (2008) Low-carbon economy and the development of building energy-saving. Construction Science and Technology (in Chinese), 24, 15-20.

[9] Sunikka, M. (2006) Energy efficiency and low-carbon technologies in urban renewal. Building Research \& Information, 34(6), 521-533.
[10] Arena, A. P. and Rosa, C. D. (2003) Life cycle assessment of energy and environmental implications of the implementation of conservation technologies in school building in Mendoza-Argentina. Building and Environmental, 38, 359-368.

[11] Chris, S., Gregory, A. K. and Peter, R. (2003) Life cycle energy and environmental performance of a new university building: Modeling challenges and design implications. Energy and Buildings, 35, 1049-1064.

[12] Gong, Z. Q. and Zhang, Z. H. (2004) A study on embodied environmental profile during the life cycle of cement. China Civil Engineering Journal (in Chinese), 37(5), 86-91.

[13] Li, S. T. (2007) Study on appraisal model of reducing construction of construction project (in Chinese). $\mathrm{Ph}$. D. thesis, Huazhong University of science and technology, Wuhan, ON, China.

[14] Yang, J. X., Xu, C. and Wang, R. S. (2002) Methodology and application of life cycle assessment (in Chinese). China Meteorological Press, Beijing.

[15] Lippiatt, B. C. (2007) Building for environmental and economic sustainability technical manual and user guide. http://www.bfrl.nist.gov/oae/software/bees/bees.html.

[16] China Building Materials Academy (2003) Green building materials and making building materials green (in Chinese). Chemical Industry Press, Beijing. 